\title{
Examination Concerning Miniaturization of the Micro-Machine using the Magnetic Torque
}

\author{
Aya Yamazaki Student Member （RIEC Tohoku Univercity, aya@riec.tohoku.ac.jp) \\ Masahiko Sendoh Member (Miyagi Organization For Industry Promotion, sendoh@riec.tohoku.ac.jp) \\ Kazushi Ishiyama Member (RIEC Tohoku Univercity, ishiyama@riec.tohoku.ac.jp)
}

Ken Ichi Arai Member (RIEC Tohoku Univercity, arai@riec.tohoku.ac.jp)

Keywords : Magnetic torque, load torque, rotational magnetic field, scaling law

The size of the micro - machine becomes $\mathrm{nm} \sim \mu \mathrm{m}$ order by the development of the micro-fabrication technology in recent years. In the microscopic world, viscous force and frictional force the gravitational and the inertial forces proportional to the second power of dimensions bocomes a predominant environment compared with the gravitational and the inertial forces proportional to the third power of dimensions. At the driving force, the magnetic force proportional to the third power of dimensions is disadvantages to miniaturization. We examined the swimming properties of a spiral-type magnetic micro-machine. Fig. 1 shows a schematic view of the micro-machine. The machine was composed of a magnet and a spiral blade. As the magnet was magnetized in the radial direction, the machine rotated in synch with the rotating external magnetic field. We found that the spiral-type structure and an analysis method were applicable under a very wide-range of Reynolds numbers $\left(10^{-7}<\operatorname{Re}<10^{3}\right)$. For this reason, this micro-machine is anticipated to miniaturization. In this paper, we examined about the driving force and drag force.

The micro-machine is rotated by the magnetic torque. The magnetic torque is given by Eq.(1).

$$
\begin{aligned}
& \mathrm{T}_{\mathrm{M}}=\mathrm{M} \cdot \mathrm{H} \sin \theta \\
& \mathrm{T}_{\mathrm{M}}: \text { Magnetic torque }[\mathrm{Nm}] \\
& \mathrm{M}: \text { Magnetization }[\mathrm{Wb} \mathrm{m}] \\
& \mathrm{H}: \text { External magnetic field }[\mathrm{A} / \mathrm{m}] \\
& \theta: \text { Phase difference between } \mathrm{M} \text { and } \mathrm{H}
\end{aligned}
$$

When the micro-machine rotates, the micro-machine receives the load torque from the fluid. The magnetic micro-machine could rotate when the magnetic torque was larger than the load torque. When the value of load torque could be estimated, the required magnetic torque could be calculated. The value of load torque could be calculated as the product of the shearing force and the distance from the rotation center. The load torque is given by a variable number of the distance and the coefficient of viscosity by Eq. (2).

$$
\begin{aligned}
\mathrm{T}_{\mathrm{L}}=\mathrm{F}_{\mathrm{S}} \cdot \mathrm{D} \\
=\tau \cdot \mathrm{A} \cdot \mathrm{D} \\
=\mu \cdot \mathrm{u} \cdot \mathrm{A} \cdot \mathrm{D} \\
\mathrm{T}_{\mathrm{L}}: \text { Load torque }[\mathrm{N} \mathrm{m}] \\
\quad \mathrm{F}_{\mathrm{S}}: \text { Shearing force }[\mathrm{N}] \\
\mathrm{D}: \text { Distance from the rotation center }[\mathrm{m}] \\
\tau: \text { Shearing stress }\left[\mathrm{N} / \mathrm{m}^{2}\right] \\
\quad \text { A: Area }\left[\mathrm{m}^{2}\right] \\
\mu: \text { Coefficient of viscosity }\left[\mathrm{N} \mathrm{s} / \mathrm{m}^{2}\right] \\
\mathrm{u}: \text { Rate of shearing deformation }[1 / \mathrm{s}]
\end{aligned}
$$

The load torque was proportional of the coefficient of viscosity, and proportional to the third power of dimensions. Therefore, the driving force and drag force are reduced at the same rate, the magnetic micro-machine rotating and driivng using the magnetic torque can be miniatuarization.

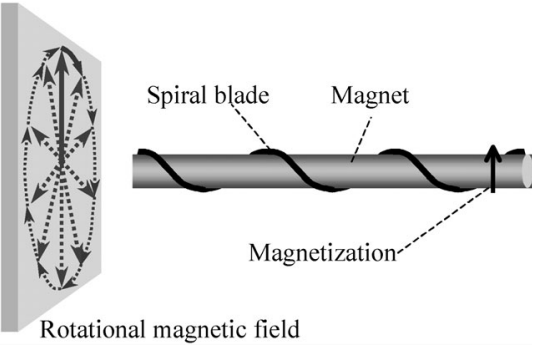

Fig. 1. Schematic view of magnetic micro-machine

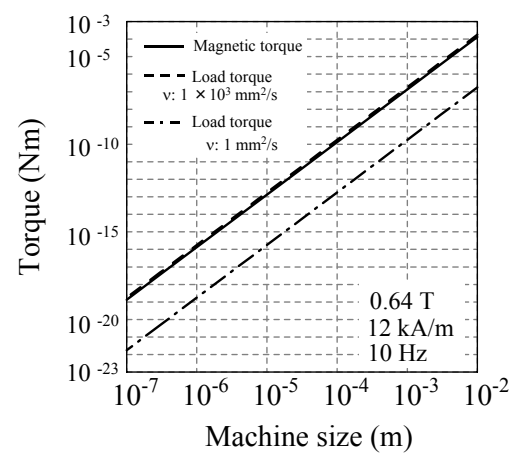

Fig. 2. Relation between torque and machine size 


\title{
磁気トルクを利用したマイクロマシンの小型化に関する検討
}

\author{
学正員 山崎 彩* 正 員 仙道 雅彦** \\ 正 員 石山 和志* 正員 荒井 賢一*
}

\section{Examination Concerning Miniaturization of the Micro-Machine using the Magnetic Torque}

Aya Yamazaki*, Student Member, Masahiko Sendoh**, Member, Kazushi Ishiyama*, Member, Ken Ichi Arai*, Member

In this paper, the limit size of a magnetic micro - machine using the magnetic torque was examined. This machine rotates according to a magnetic torque and is promoted. The limit of the miniaturization of the machine was examined by requesting the relation between a magnetic torque and the load torque. In the case of the rotating and driving magnetic micro-machine, the driving force and the drag decrease at the same rate. Therefore, the magnetic micro-machine can swim even if the machine becomes miniaturization.

キーワード：磁気トルク，負荷トルク，回転磁界，スケーリング則

Keywords : Magnetic torque, load torque, rotational magnetic field, scaling law

\section{1. はじめに}

近年，マイクロマシンのサイズは，加工技術の進歩と供 に, $\mathrm{nm} \sim \mu \mathrm{m}$ オーダとなっている。一般にミクロの世界では, 寸法の 3 乗に比例する体積力が相対的に弱くなり，寸法の 2 乗に比例する面積力が支配的になる（スケーリング則 ${ }^{(1)}$ )。 抵抗力で考えると，寸法の 3 乗に比例する重力や慣性力よ り，寸法の 2 乗に比例する摩擦力, 表面張力, 粘性力が支 配的になる。駆動力に関しては，一般的に，寸法の 3 乗に 比例する磁気力より, 寸法の 2 乗に比例する静電力がマイ クロマシンの小型化に対して有効な駆動方法であると考え られている。また，ミクロの世界では寸法の 2 乗に比例す る抵抗力が大きな問題となるため, マイクロマシンを駆動 する際のエネルギー供給や制御用のケーブルは大きな障害 となる(2)。つまり，エネルギ一供給やマシンの移動制御をワ イヤレスに行えることは, マイクロマシンの小型化におい ては必要であると考えられる。このようなワイヤレス駆動 可能な駆動方法のひとつに磁気力が挙げられる。これまで に磁気力を用いて液体 ${ }^{(3)(4)}$, 気体 ${ }^{(5)(6)}$, 固体中 ${ }^{(7)}$ を自立移動す るマイクロマシンの研究が報告されている。本論文では, 液体中を駆動するマイクロマシンに焦点を絞り, 図 1 に示 すスパイラル型磁気マイクロマシンについて検討を行った

\footnotetext{
* 東北大学電気通信研究所

干980-8577 宮城県仙台市青葉区片平 2-1-1

RIEC, Tohoku Univ.

2-1-1 Katahira Aoba-ku, Sendai Miyagi 980-8577

** みやぎ産業振興機構

干980-0011 宮城県仙台市青葉区上杉 1-14-2

Miyagi Organization For Industry Promotion

1-14-2 Kamisugi Aoba-ku Sendai, Miyagi 980-0011
}

(3)。このマイクロマシンは, 磁石とスパイラル形状に加工さ れたワイヤから構成されている。このマイクロマシンは搭 載した磁石に外部から磁界を印加して発生する磁気トルク を利用して駆動するため, ワイヤレスに駆動可能である。 これまでの研究において, マシン直径 $0.1 \sim 1.5 \mathrm{~mm}$ のマシン を用いて，(1)式で表されるレイノルズ数 ${ }^{(8)}$ が $10^{-7} \sim 10^{3}$ と幅広い条件下において実験と解析により検討が行われて いる(3)(9),(10)

$$
\mathrm{Re}=\mathrm{L} \cdot \mathrm{S} / \mathrm{v}
$$

ここに, Re : レイノルズ数, L : 代表長さ $\mathrm{S}$ : 代表速度, $v$ : 液体の動粘度

さらに, 印加磁界面の制御によりマシンをワイヤレスで方 向制御可能であることが示されている(11)。従って, スパイ ラル型構造のマイクロマシンは, 構造の面から小型化が期 待される。

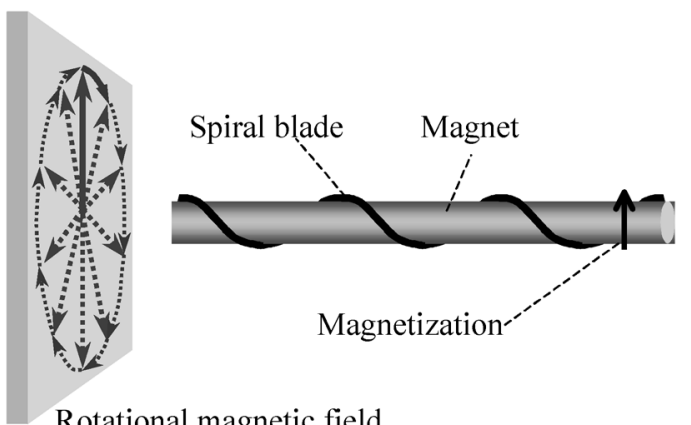

Rotational magnetic field

図 1 磁気マイクロマシンの概略図

Fig. 1. Schematic view of magnetic micro-machine. 
本論文では, 磁気力を用いた磁気マイクロマシンがどこ まで小さくできるかについて検討を行った。このとき，小 型化の条件として，以下の項目を設定した。

1. マシンに搭載する磁石の残留磁束密度は一定

2. マシンは均一磁場中を駆動

3. 印加磁界強度は一定

4. マシンの寸法比を一定で小型化

以上の条件のもと, マシンサイズと抵抗力, 駆動力との 関係を明らかにし，磁気トルクを用いたマイクロマシンの 小型化の限界について検討を行った。

\section{2. マシンに働くトルクとカ}

〈2·1〉回転方向本論文で検討を行う磁気マイクロ マシンは, 図 2 に示す磁気トルクを利用している。磁気卜 ルクは(2)式で表されるように, 磁石の磁気モーメント $\mathrm{M}$ と磁界 Hによって表される。

$\mathrm{T}_{\mathrm{M}}=\mathrm{M} \cdot \mathrm{H} \cdot \sin \theta$

ここに, $\mathrm{T}_{\mathrm{M}}$ : 磁気トルク $[\mathrm{Nm}], \mathrm{M}$ : 磁気モーメン

卜 $[\mathrm{Wb} \cdot \mathrm{m}], \mathrm{H}:$ 外部印加磁界強度 $[\mathrm{A} / \mathrm{m}], \theta: \mathrm{M}$

と $\mathrm{H}$ の位相差

また, 磁気モーメント M は( 3 )式で表される。

$\mathrm{M}=\mathrm{B}_{\mathrm{r}} \cdot \mathrm{V}$

ここに, $\mathrm{M}$ : 磁気モーメント $[\mathrm{Wb} \cdot \mathrm{m}], \mathrm{B}_{\mathrm{r}}$ : 残留磁 束密度 $[\mathrm{T}], \mathrm{V}$ : 磁石の体積 $\left[\mathrm{m}^{3}\right]$

ここで(3)式より, 磁気モーメントは体積に比例することか ら, 寸法の 3 乗に比例する。従って, (2)式より, 印加磁界 強度を一定としたとき磁気トルクは磁気モーメント M に比 例することから，寸法の 3 乗に比例する。

一方, 回転した磁気マイクロマシンは, 流体から負荷卜 ルクを受ける。磁気トルク $\mathrm{T}_{\mathrm{m}}$ と負荷トルク $\mathrm{T}_{\mathrm{L}}$ の関係を図 3 に示す。磁気マイクロマシンが回転するためには, 負荷卜 ルクを上回る磁気トルクが必要である。従って, 負荷トル クと寸法の関係を明らかにすることで，マイクロマシンの 小型化の限界を見積もることが可能となる。負荷トルクの 主な要因は, (4)式で表されるマシンの表面に㗢くせん断力 である。

$$
\mathrm{F}_{\mathrm{s}}=\tau \cdot \mathrm{A}
$$

ここに, $\mathrm{F}_{\mathrm{s}}$ : せん断力 $[\mathrm{N}], \tau$ : せん断応力

$\left[\mathrm{N} / \mathrm{m}^{2}\right], A$ : 表面積 $\left[\mathrm{m}^{2}\right]$

回転方向の抵抗力であることから, せん断力と回転半径の 積で表される負荷トルクが磁気トルクに対する抵抗力とな る(( 5$)$ 式)。

$$
\begin{aligned}
\mathrm{T}_{\mathrm{L}} & =\mathrm{F}_{\mathrm{S}} \cdot \mathrm{D} \\
& =\tau \cdot \mathrm{A} \cdot \mathrm{D} \\
& =\mu \cdot \mathrm{u} \cdot \mathrm{A} \cdot \mathrm{D}
\end{aligned}
$$

ここに, $\mathrm{T}_{\mathrm{L}}$ : 負荷トルク $[\mathrm{Nm}], \mathrm{F}_{\mathrm{s}}$ ：せん断力

$[\mathrm{N}], \mathrm{D}:$ 回転半径 $[\mathrm{m}], \tau$ : せん断応力 $\left[\mathrm{N} / \mathrm{m}^{2}\right]$,

A : 表面積 $\left[\mathrm{m}^{2}\right], \mu$ : 液体の粘性 $\left[\mathrm{N} \mathrm{s} / \mathrm{m}^{2}\right], \mathrm{u}$ : 変位速度 $[1 / \mathrm{s}]$

従って, 負荷トルクは寸法の 2 乗に比例するせん断力と寸
法の 1 乗に比例する回転半径の積で表されるため, 寸法の 3 乗に比例し, 液体の粘性の 1 乗に比例する。図 4 に周波数 $10 \mathrm{~Hz}$ における液体の粘性に対するマシンサイズとトルク の計算結果を示す。破線と一点鎖線がそれぞれ動粘度 $1 \times$ $10^{3}, 1 \mathrm{~mm}^{2} / \mathrm{s}$ における負荷トルクである。実線は, (2)式を 用いて求めた磁気トルクであり, 磁石の残留磁束密度, 印

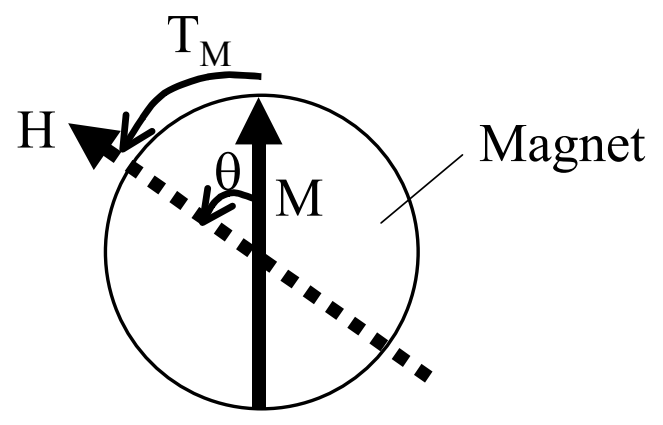

図 2 磁気トルクの概略図

Fig. 2. Schematic view of magnetic Torque.

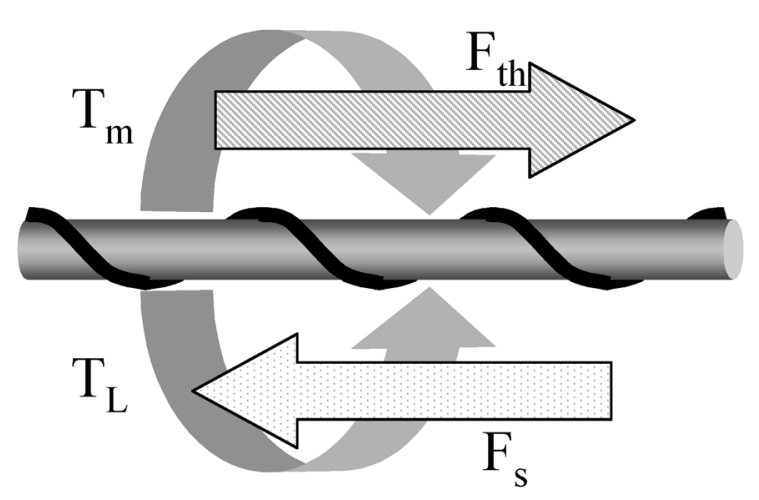

図 3 回転するマイクロマシンに働く力と トルクの関係

Fig. 3. Relation between force and torque of machine.

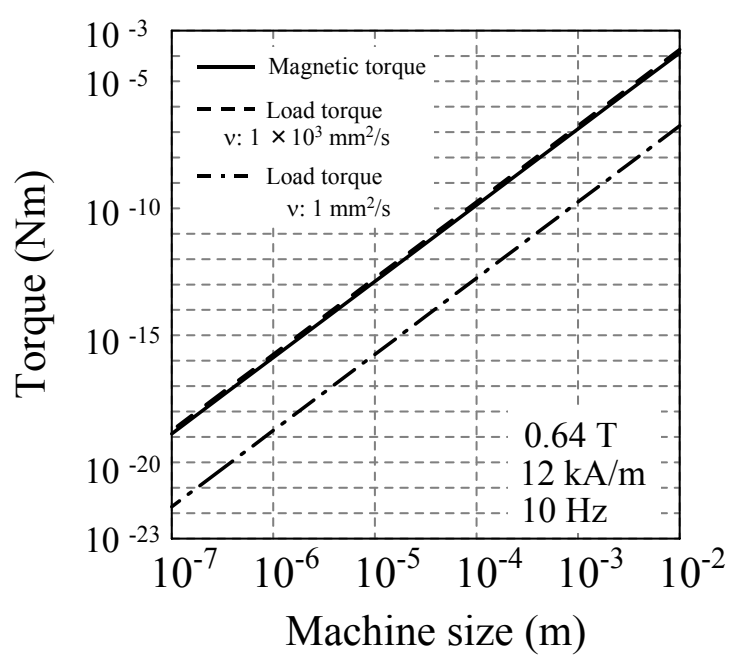

図 4 マシンサイズとトルクの関係

Fig. 4. Relation between torque and machine size. 


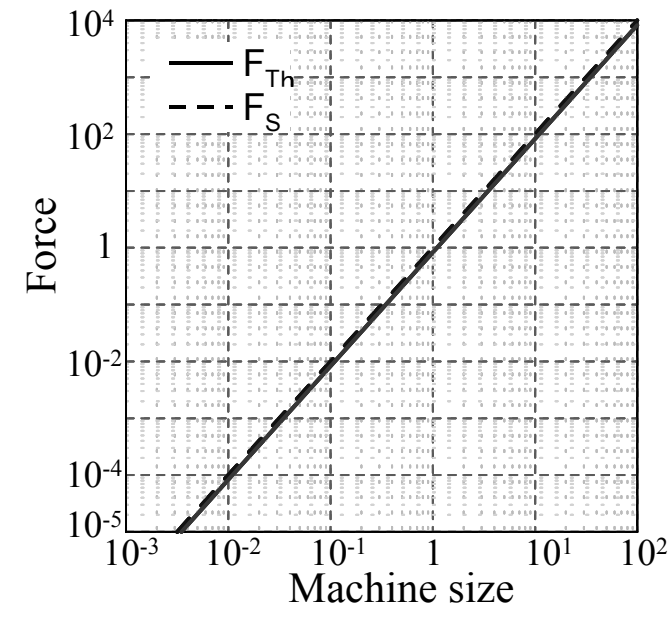

図 5 マシンサイズに対する推力と抵抗力の関係

Fig. 5. Relation between force and machine size.

加磁界強度をそれぞれ $0.64 \mathrm{~T}, 12 \mathrm{kA} / \mathrm{m}$ とした。ここで, 動 粘度 $1 \times 10^{3} \mathrm{~mm}^{2} / \mathrm{s}$ における負荷トルクと磁気卜ルクが等し いと仮定する。この結果より，負荷トルク，磁気トルクと も寸法の 3 乗に比例して減少するため, マシンサイズを小 さくしても駆動可能である。また, 負荷トルクは粘性の 1 乗に比例するため, 液体の粘性を $10^{-3}$ 倍にすると負荷トル クは $10^{-3}$ 倍小さくなる。従って, マシンサイズを小さくし ても駆動可能であり, 液体の粘性を小さく寸ることで, さ らに小さい磁気トルクで駆動可能であることが明らかとな った。

〈2·2〉推進方向磁気トルクにより回転したマイク ロマシンはブレード部分で生じた圧力差が推力となり, マ シンは推進する。推力の式を(6)式に示す。

$$
\mathrm{F}_{\mathrm{Th}}=\mathrm{P} \cdot \mathrm{A}
$$

ここに, $\mathrm{F}_{\mathrm{Th}}$ : 推力 $[\mathrm{N}], \mathrm{P}$ : 圧力差 $\left[\mathrm{Pa} / \mathrm{m}^{2}\right]$,

$\mathrm{A}$ : 表面積 $\left[\mathrm{m}^{2}\right]$

推力に対する抵抗力は, (4)式で表されるマシン表面に働く せん断力である。従って (4), (6)式より, 推力, 抵抗力は 寸法の 2 乗に比例する。図 5 に, マシンサイズに対する, 推力と抵抗力の関係を示す。マシンサイズ 1 の時、推力、 抵抗力は 1 と仮定した。推力と抵抗力は同じ割合で減少す るため，マシンを小型化しても推進可能であることが明ら かとなった。ここで, 推進方向に磁気力を加えてマシンを 推進させる場合について検討を行う。これは例えば図 6 に 示寸磁場勾配の力でマシンを引っ張って動か寸場合に相当 する。磁場勾配による力 $\mathrm{F}_{\mathrm{g}}$ は(7)式で表されるように, 寸 法の 3 乗に比例する。

$$
\mathrm{F}_{\mathrm{g}}=\mathrm{M} \mathrm{dH} / \mathrm{dX}
$$

ここに， $\mathrm{F}_{\mathrm{g}}$ : 磁場勾配による力 $[\mathrm{N}], \mathrm{M}$ : 磁 気モーメント $[\mathrm{Wb} \cdot \mathrm{m}], \mathrm{dH} / \mathrm{dX}$ : 磁場勾配 $\left[\mathrm{A} / \mathrm{m}^{2}\right]$

対する抵抗力は, (4)式で表されるマシン表面に働くせん断 力である。図 7 にマシンサイズに対する磁場勾配による力 と抵抗力の関係を示す。図 5 と同様に, マシンサイズ 1 の

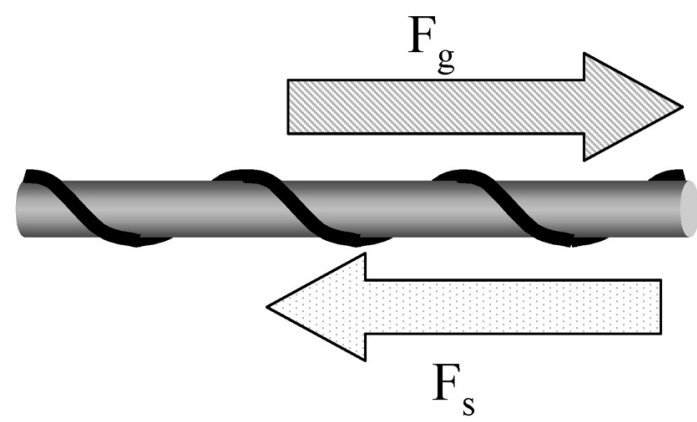

図 6 マシンに働く磁場勾配の力と抵抗力の関係

Fig. 6. Relation between magnetic gradient and drag.

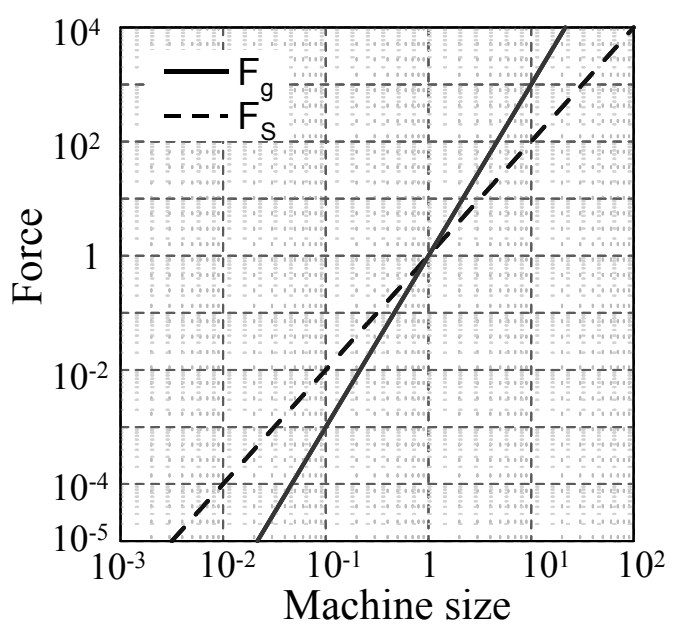

図 7 マシンサイズに対するマシンに働く力の関係

Fig. 7. Relation between force and machine size.

時、推力、抵抗力は 1 と仮定した。マシンサイズを小さく した場合, 抵抗力は寸法の 2 乗に比例して減少寸るのに対 し, 磁場勾配の力は寸法の 3 乗に比例して減少する。従っ て, マシンサイズの減少により, 抵抗力が磁場勾配による 力を上回り動作不可能となるため, マイクロマシンの駆動 力として磁気力は不利であると考えられている。

以上の結果より, 磁気トルクが駆動力であり, 負荷トル クが抵抗力となる, 回転し推進する磁気マイクロマシンは マシンを小型化しても推進可能であることが示された。

\section{3. 実 験}

〈3·1〉素子構成 第 2 章で検討した負荷トルクとマ シンサイズの関係を検討するために，ミリサイズのマシン と数十 $\mu \mathrm{m}$ サイズのマシンを作製した。図 8 に作製したミ リサイズの平面型磁気マイクロマシンの写真を示す。数十 $\mu \mathrm{m}$ サイズのマシンを薄膜を用いて作製することを考慮し てブレードの一部分を平面的に取り出した構造とした (12)(13)。このマイクロマシンは, $\mathrm{SmFeN}$ 磁石 $(\phi 1.2 \times 0.55 \mathrm{~mm})$ とプラスチック板 (厚さ; $0.2 \mathrm{~mm}$, 幅; 0.2, 0.8, $1 \mathrm{~mm}$ ) から 構成されている。3 種類の幅のプラスチック板は磁石の周り に階段状に並べられ, 傾斜が磁石を挟んで逆方向となるよ うに配置されている。マイクロマシンの厚さは $0.6 \mathrm{~mm}$ であ 
り, マシン全体の長さは 3 10 mm とした。これを mm-Type とする。図 9 に製作した数十 $\mu \mathrm{m}$ サイズのマイクロマシン の SEM 写真を示す。このマイクロマシンは $\mathrm{Cu}$ と $\mathrm{Ti}$ 薄膜, 駆動用の磁石として SmCo 薄膜磁石をスパッタリング法を 用いて成膜し作製した。マシンの形状は，ミリサイズのマ シンと同様に幅の異なる 3 種類の薄膜を積層し, 傾斜を作 製した。これを $\mu \mathrm{m}$-Type とする。各層の構成は，1層目に， $\mathrm{Cu}, \mathrm{Ti}, \mathrm{SmCo}$ 薄膜をそれぞれ $2 \mu \mathrm{m}, 1 \mu \mathrm{m}, 1 \mu \mathrm{m}$ 成膜し, 2，3 層目は $\mathrm{Ti} ， \mathrm{Cu}$ をそれぞれ $1 \mu \mathrm{m} ， 3 \mu \mathrm{m}$ 成膜した。それ ぞれの膜の厚さは $4 \mu \mathrm{m}$ としたので, マシン全体の厚さは 12 $\mu \mathrm{m}$ となった。膜の幅は 1 層目から $30 \mu \mathrm{m}, 20 \mu \mathrm{m}, 10 \mu \mathrm{m}$ で

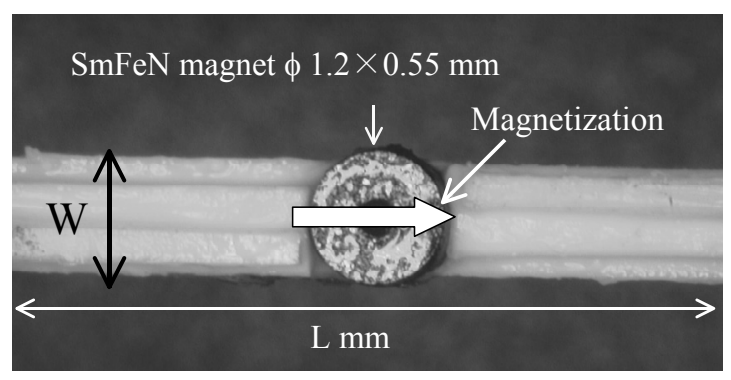

(a) Top view

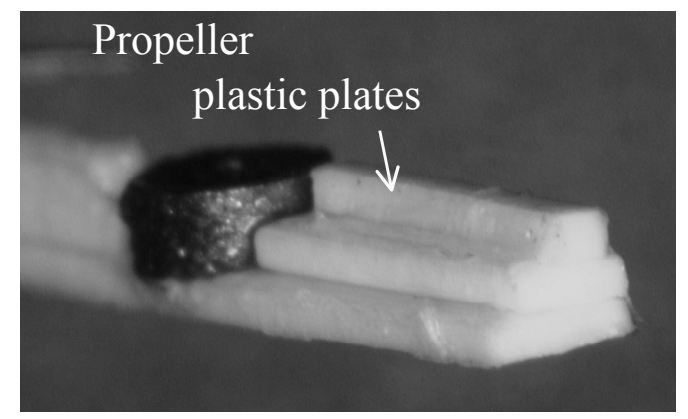

(b) Side view

図 8 平面型磁気マイクロマシン (mm-Type) Fig. 8. Magnetic micro-machine of plane structure (mm-Type).

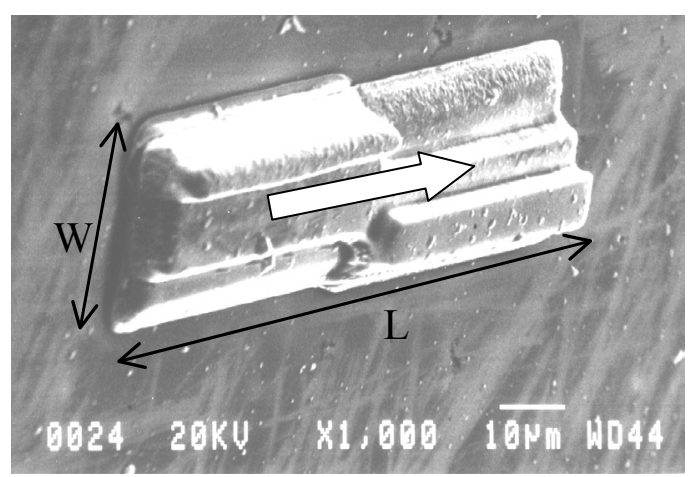

図 9 平面型磁気マイクロマシンの SEM 写真

( $\mu \mathrm{m}$-Type)

Fig. 9. SEM photograph of the magnetic micro-machine of planar structure ( $\mu \mathrm{m}$-Type).
ある。マシンの長さは $60 \mu \mathrm{m}, 80 \mu \mathrm{m}, 100 \mu \mathrm{m}, 120 \mu \mathrm{m}$ の 4 種類作製した。両タイプとも, 磁石の磁化方向は, 図 8 , 図 9 の矢印に示すマシンの長手方向とした。外部から回転磁界 を印加するとマシンが回転し, マシンは図 10 に示すマシン の厚さ方向に推進する。また，作製の都合上，マシンの幅 $\mathrm{W}$ は一定とし, マシンの長さ L のみを変化させて作製した。

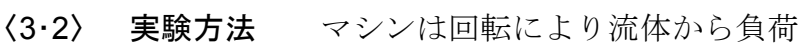
トルクを受ける。マシンの回転周波数の増加と共に負荷卜 ルクは増加し, ある周波数を越えるとマシンの回転は回転 磁界の同期から外れる。この周波数を脱調周波数と定義す る。この脱調周波数において, 負荷トルクと磁気トルクは 等しいため, 脱調周波数と磁気トルクの関係を測定するこ とで，負荷トルクの測定を行った。実験には，mm-Type， $\mu \mathrm{m}$-Type それぞれ, 動粘度 $1 \times 10^{3} \mathrm{~mm}^{2} / \mathrm{s}, 0.65 \mathrm{~mm}^{2} / \mathrm{s}$ のシリ コーンオイルを使用した。 mm-Type のマシンは, シリコー ンオイルで満たされた直径 $16 \mathrm{~mm}$ の試験管内にマシンを入 れ, 外部から $12 \mathrm{kA} / \mathrm{m}$ の回転磁界を印加し, 脱調周波数を 測定した。このとき印加磁界強度と磁石の磁気モーメント

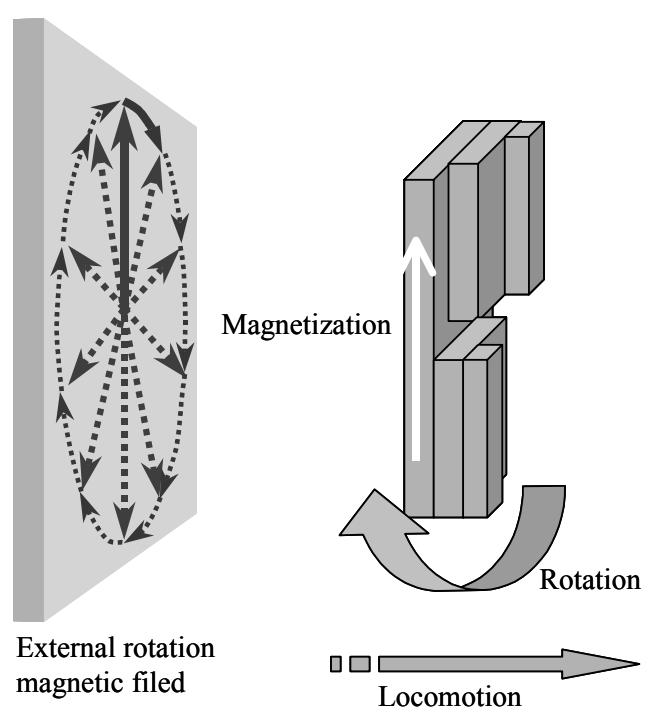

図 10 平面型磁気マイクロマシンの回転方向と推 進方向

Fig. 10. Schematic view of the direction of the rotation and direction of the locomotion.

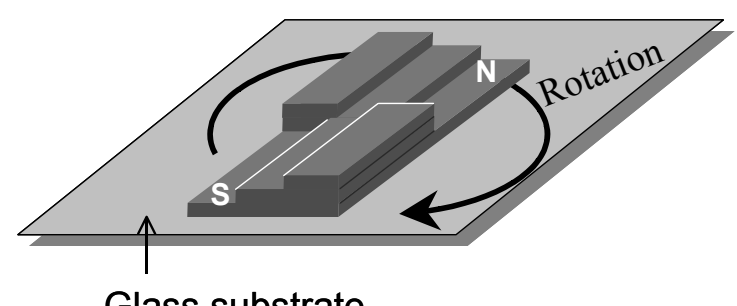

図 11 負荷トルクの測定方法の概略図 ( $\mu \mathrm{m}$-Type) Fig. 11. Schematic view of the direction of the rotation and direction of the locomotion ( $\mu \mathrm{m}$-Type). 
から計算される磁気トルクは(2)式より与えられる。実験に 使用した磁石の残留磁束密度は $0.32 \mathrm{~T}$ であり, 外部印加磁 界強度は $12 \mathrm{kA} / \mathrm{m}$ であるので, 磁気トルクは $4.8 \mu \mathrm{Nm}$ と計 算される。 $\mu$ m-Type のマシンを用いた実験系を図 11 に示す。 マシンを載せた基板をシリコーンオイルで満たされた容器 に入れ，基板に平行な回転磁界を印加しマシンを回転させ る。回転磁界の強度を変化させて脱調周波数の測定を行っ た。磁気トルクは, 成膜した磁石の残留磁束密度の実測值 $0.9 \mathrm{~T}$ と回転磁界強度から(2)式を用いて求めた。回転周波 数が $3 \mathrm{~Hz}$ 以上になると, 回転の様子を観察することが困難 となるため, 周波数は $3 \mathrm{~Hz}$ 以下で測定を行った。

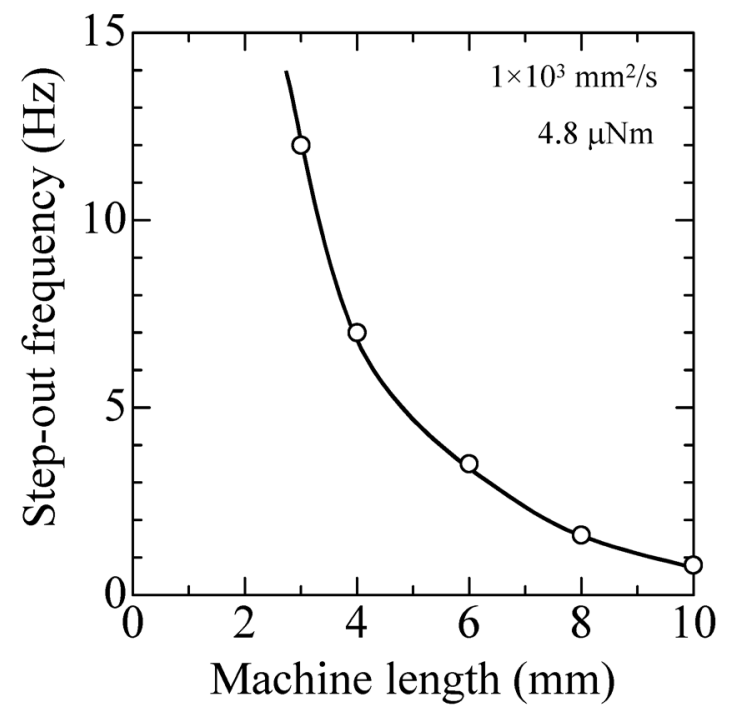

図 12 マシンサイズと脱調周波数の実験結果 (mm-Type)

Fig. 12. Relation between step-out frequency and machine size L (mm-Type).

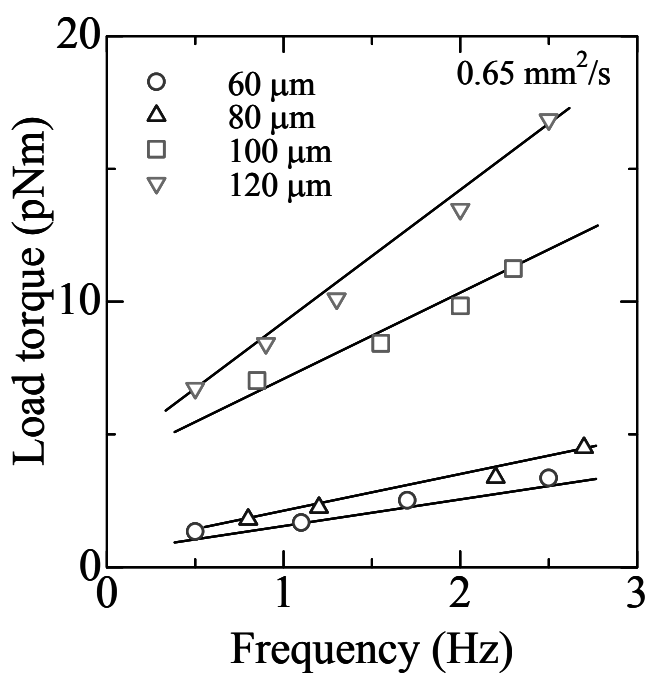

図 13 周波数と負荷トルクの実験結果 (mm-Type)

Fig. 13. Relation between load torque and frequency (mm-Type).
〈3·3〉実験結果図12にmm-Typeのマシンを用いた マシン長さに対する脱調周波数の実験結果を示す。実験の 結果, マシン長さの増加に伴い, 脱調周波数は減少した。 従って, 同一周波数における負荷トルクはマシン長さの増 加に伴い増加した。(5)式より, 負荷トルクは表面積と回転 半径に比例する。本実験では, マシンの幅を W と一定とし, マシンの長さ L を変化させている。従って, (5)式より, 負 荷トルクは, (8)式で表される。

$$
\begin{aligned}
\mathrm{T}_{\mathrm{L}} & =\mu \cdot \mathrm{u} \cdot \mathrm{A} \cdot \mathrm{D} \\
& =\mu \cdot \mathrm{u} \cdot(2 \cdot \mathrm{W} \cdot \mathrm{L}) \cdot \mathrm{L} / 2
\end{aligned}
$$

ここに, $\mathrm{T}_{\mathrm{L}}$ : 負荷トルク $[\mathrm{Nm}], \mathrm{D}$ : 回転半径 $[\mathrm{m}], \mathrm{A}$ : 表面積 $\left[\mathrm{m}^{2}\right], \mu$ : 液体の粘性 $\left[\mathrm{N} \mathrm{s} / \mathrm{m}^{2}\right]$, $\mathrm{u}$ : 変位速度 $[1 / \mathrm{s}], \mathrm{W}$ :マシン幅 $[\mathrm{m}], \mathrm{L}:$ マシン 長さ $[\mathrm{m}]$

従って，マシンの長さ L の 2 乗に比例して増加したと考 えられる。一方, 図 13 に, $\mu \mathrm{m}$-type のマシンを用いた周波 数に対する負荷トルクの実験結果を示す。各マシン長さに おいて, 周波数に比例して負荷トルクは増加し, マシン長 さの増加に伴い負荷トルクが増加した。これは, mm-Type のマシンと同様の結果が得られた。

〈3.4〉考察実験結果から, マシンサイズと負荷卜 ルクの関係について検討を行うために, 幅と長さの比が約 1 対 3 の形状を用いて比較を行った。mm-Type のマシンより, 幅 $1 \mathrm{~mm}$, 長さ $3 \mathrm{~mm}$ のマシンは $12 \mathrm{~Hz}$ のとき負荷トルクが $4.8 \mu \mathrm{Nm}$ となり, $1 \mathrm{~Hz}$ 当りの負荷トルクは $0.4 \mu \mathrm{Nm}$ となっ た。それに対して, mm-Type の約 1/33 倍となる幅 $30 \mu \mathrm{m}$, 長さ $80 \mu \mathrm{m} の \mu \mathrm{m}$-Type のマシンは, 約 $3 \mathrm{~Hz}$ のとき負荷トル クは $5 \mathrm{pNm}$ となり, $1 \mathrm{~Hz}$ 当りの負荷トルクは約 $1.6 \mathrm{pNm}$ と なった。(3)式より負荷トルクは液体の粘性に比例すること から, mm-Type と $\mu \mathrm{m}$-Type の実験に用いた液体の粘性が約 $10^{3}$ 倍であることを考慮して， $\mu \mathrm{m}$-Type の負荷トルクは mm-Type の約 1/250 倍の負荷トルクと予想より大きな值と なった。これは, mm-Type のマシンは, 壁から十分離れた 位置で回転しているため, 回転による流体からの負荷トル クのみである。それに対し， $\mu \mathrm{m}$-Type のマシンは，基板上で 回転しているため, 回転による流体からの負荷トルクの他 に，基板との摩擦による負荷トルクの影響を受け，全体の 負荷トルクが大きくなったと考えられる。従って, マシン の小型化による負荷トルクの減少率はマシンサイズの 3 乗 より大きなものとなったが, 数十 $\mu \mathrm{m}$ まで小型化したマイ クロマシンは数 $\mathrm{pNm}$ の磁気トルクで駆動可能であり, 膜厚 $1 \mu \mathrm{m}$ の薄膜磁石で実現可能であることが示された。

\section{4. まとめ}

本論文では，マシンの小型化には不利であると考えられ ている磁気力を用いた磁気マイクロマシンの小型化につい て検討を行った。検討の結果, 磁気マイクロマシンの駆動 力である磁気卜ルクと抵抗力である負荷トルクはそれぞれ 寸法の 3 乗に比例することを明らかにした。従って，回転 し推進する磁気マイクロマシンは, 駆動力, 抵抗力共に寸 
法の 3 乗に比例するため, マシンの小型化にはスケーリン グ則の制限を受けないことを明らかにした。

(平成 17 年 11 月 25 日受付, 平成 18 年 6 月 6 日再受付)

\section{文献}

(1) M. Esashi : "Physics of the Micro World and Micromachines", J. Rob. Soc. Jpn., Vol.14, No.8, pp.1086-1089 (1996) (in Japanese)

江刺正喜:「微小世界の物理学とマイクロマシン」, 日本ロボット学 誌, 14, 8, pp.1086-1089 (1996)

(2) I. Shimoyama : "Scale Effects in Microrobots", J. Rob. Soc. Jpn., Vol.14, No.8, pp.1106-1108 (1996) (in Japanese)

下山 勲:「マイクロロボットのスケール効果」, 日本ロボット学誌, 14, 8 pp.1106-1108 (1996)

(3) M. Sendoh, K. Shimazaki, K. Ishiyama, M. Inoue, and K. I. Arai : "Swimming Properties of Spiral-Type Magnetic Micro-machines", $J$. Magn. Soc. Jpn., Vol.23, No.4-2, pp.1657-1660 (1999) (in Japanese) 仙道雅彦・島崎克彦・石山和志・井上光輝・荒井賢一 :「スパイラル 形状を基本とした泳動型磁気マイクロマシンの泳動特性」, 応用磁気 学誌, 23, 4-2, pp.1657-1660 (1999)

(4) M. Tomie, A. Takiguchi, T. Honda, and J. Yamasaki : "Turning Performance of Fish-Type Microrobot Driven by External Magnetic Field", IEEE Trans. Magn., Vol.41, No.10, pp.4015-4017 (2005)

(5) K. I. Arai, W. Sugawara, K. Ishiyama, T. Honda, and M. Yamaguchi : "Fabrication of small flying machines using magnetic thin films", IEEE Trans. Magn., Vol.31, No.6, pp.3758-3760 (1995)

(6) N. Miki and I. Shimoyama : "Soft-Magnetic Rotational Microwings in an Alternating Magnetic Field Applicable to Microflight Mechanisms", IEEE J Microelectromec. Syst., Vol.12, No.2, pp.221-227 (2003)

( 7 ) K. Ishiyama, M. Sendoh, A. Yamazaki, and K. I. Arai : "Swimming micro-machine driven by magnetic torque”, Sens. Actuators. A, Vol.91, No.1-2, pp.141-144 (2001)

(8) T. Kambe : "Fluid Dynamics", Shokabo (1995) (in Japanese) 神部 勉:「流体力学」, 裳華房 (1995)

(9) A. Yamazaki, M. Sendoh, K. Ishiyama, T. Hayase, and K. I. Arai : "Three-Dimensional Analysis of Swimming Properties of the Spiral-Type Magnetic Micro-Machine”, Sens. Actuators. A, Vol.105, No.1, pp.103-108 (2003)

(10) A. Yamazaki, M. Sendoh, K. Ishiyama, K. I. Arai, R. Kato, M. Nakano, and H. Fukunaga : "Wireless Micro Swimming Machine With Magnetic Thin Film”, JMMM, Vol.272-276, No.4, pp.e1741-e1742 (2004)

(11) M. Sendoh, A. Yamazaki, K. Ishiyama, K. I. Arai, and M. Inoue : "Wireless Controlling of the Swimming Direction of the Spiral-Type Magnetic Micro-Machines", Trans. IEE Japan, Vol.120-A, No.3, pp.301-306 (2000-3) (in Japanese)

仙道雅彦・山崎 彩・石山和志・荒井賢一・井上光輝 :「スパイラル 型磁気マイクロマシンのワイヤレス泳動方向制御, 電学論 $\mathrm{A}, \mathbf{1 2 0}, 3$, pp.301-306 (2000-3)
(12) A. Yamazaki, M. Sendoh, K. Ishiyama, K. Morooka, and K. I. Arai : "Fabrication of Magnetic Micro-Machine of Planar Structure", J. Magn. Soc. Jpn., Vol.29, No.2, pp.157-160 (2005) (in Japanese)

山崎 彩・仙道雅彦・石山和志・師岡ケイ子・荒井賢一:「平面型構 造の磁気マイクロマシンの試作」, 応用磁気学誌, 29, 2, pp.157-160 (2005)

(13) A. Yamazaki, M. Sendoh, K. Ishiyama, and K. I. Arai : "Wireless Magnetic Micro-Machine of Planar Structure with Magnetic Thin Film", IEEE Trans. Magn., Vol.41, No.10, pp.4021-4023 (2005)

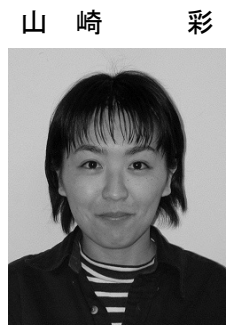

(学生員) 2000 年 3 月東北大学工学部電気工学 科卒業。2005 年 9 月東北大学大学院工学研究科 電気通信工学専攻後期課程修了。同年 10 月東 北大学電気通信研究所研究生。現在に至る。

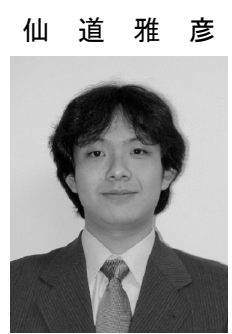

（正員） 1999 年 3 月東北大学工学部電気工学 科卒業。2002 年 4 月日本学術振興会特別研究員 (DC)。2003 年 3 月東北大学大学院工学研究科電 気通信工学専攻後期課程修了。2004 年 4 月東北 大学電気通信研究所助手。2005 年 4 月（財）み やぎ産業振興機構研究員。現在に至る。

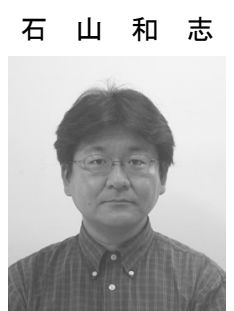

（正員） 1986 年東北大学工学部電気工学科卒 業。1988 年 3 月東北大学大学院工学研究科電子 工学専攻博士前期課程修了。同年 4 月東北大学 電気通信研究所助手。2003 年 1 月東北大学電気 通信研究所助教授。現在に至る。

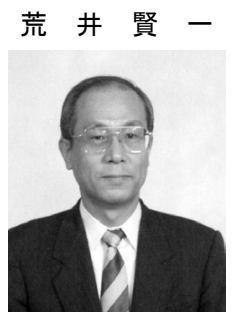

（正員） 1966 年東北大学工学部電子工学科卒 業。1971 年東北大学大学院博士課程修了。同年 東北大学助手, 電気通信研究所。1975 年東北大 学助教授, 電気通信研究所 1986 年東北大学教 授, 電気通信研究所。現在に至る。 